\title{
Pharmacokinetics of Amikacin after Repetitive Intravenous Administration in Healthy Goats
}

\author{
Namrata Upadhyay ${ }^{1}$, Nitesh Kumar ${ }^{1}$, Arpita Shrivastav ${ }^{1}$, Manoj Kumar Ahirwar ${ }^{2}$, Swatantra Singh ${ }^{1}$, \\ Neeraj Shrivastava ${ }^{3}$ and Rajeev Ranjan ${ }^{1 *}$ \\ ${ }^{1}$ Department of Veterinary Pharmacology \& Toxicology, College of Veterinary Science \& A.H., Rewa, (NDVSU, Jabalpur), \\ Madhya Pradesh, INDIA \\ ${ }^{2}$ Department of Veterinary Physiology and Biochemistry, College of Veterinary Science E A.H., Rewa, (NDVSU, Jabalpur), \\ Madhya Pradesh, INDIA \\ ${ }^{3}$ Department of Veterinary Microbiology, College of Veterinary Science \& A.H., Rewa, (NDVSU, Jabalpur), \\ Madhya Pradesh, INDIA \\ *Corresponding author; R Ranjan; E-mail: rajeev2049@gmail.com
}

Received: 26 Sept., 2020

Revised: 14 Dec., 2020

Accepted: 15 Dec., 2020

\begin{abstract}
Pharmacokinetic of amikacin was carried out in clinically healthy female goats of Sirohi breed following multiple once daily dose (@10 mg/kg bwt I/V) for five days. Concentrations of amikacin in blood plasma were estimated by microbiological assay technique and various kinetic parameters were calculated using two compartment open model. The minimum therapeutic concentration ( $\geq 1.0 \mu \mathrm{g} / \mathrm{ml}$ ) was maintained up to $12 \mathrm{~h}$ in both $1^{\text {st }}$ and $5^{\text {th }}$ day of drug administration. The drug was detectable up to $24 \mathrm{~h}$. Significantly higher plasma concentrations of the drug appeared at $0.042,0.83,0.50,0.75,2,4,8,12 \mathrm{~h}$ except $0.166,0.25,1.0,1.5,6,24 \mathrm{~h}$ on $5^{\text {th }}$ day as compared to $1^{\text {st }}$ day of drug administration. Following multiple once daily I/V administration, the values of the extrapolated zero time concentration of the drug during distribution phase (A), theoretical zero time concentration $\left(\mathrm{C}_{\mathrm{p}}{ }^{\mathrm{o}}\right)$, mean residential time (MRT) and elimination of drug from central compartment (Kel) remained nonsignificant, while significantly lower value of elimination rate constant $(\beta)$, significantly increased value of elimination phases (B), area under curve (AUC), area under first moment curve (AUMC) and total body clearance $\left(\mathrm{Cl}_{\mathrm{B}}\right)$ were observed in $5^{\text {th }}$ day as compared to $1^{\text {st }}$ day of amikacin administration. From these kinetic parameters, the loading $\left(D^{*}\right)$ and maintenance $\left(D^{0}\right)$ doses of $07.02 \pm 0.36$ and $05.91 \pm 0.15 \mathrm{mg} / \mathrm{kg}$ bwt I/V , respectively were calculated for maintaining the therapeutic concentration $\left(\mathrm{C}_{\mathrm{p}}^{\infty}\right.$ $\min =$ MIC) of $1.0 \mu \mathrm{g} / \mathrm{ml}$ at the dosage interval of $12 \mathrm{~h}$.
\end{abstract}

\section{HIGHLIGHTS}

(0) Pharmacokinetics of amikacin after repetitive intravenous administration in goats.

(0) The elimination half-life $\left(\mathrm{t}_{1 / 2} \beta\right)$ of amikacin was $4.75 \mathrm{~h}$.

( The loading doses ( $\mathrm{D}^{*}$ ) of amikacin was $07.02 \mathrm{mg} / \mathrm{kg}$ bwt I/V.

Keywords: Amikacin, goat, pharmacokinetics, dosage

Aminoglycosides are a group of antibiotics primarily used to treat a wide spectrum of microbial infections (Houghton et al., 2010). Unfortunately, as it is the case with all other antibiotics, bacteria developed several mechanisms of resistance which challenges the utility of these antibiotics. The enzymes which catalyzes inactivation of aminoglycosides are aminoglycoside acetyl-transferases, aminoglycoside nucleotidyltransferases or aminoglycoside phosphor-transferases. These enzymes are the leading cause of the rapid increase

How to cite this article: Upadhyay, N., Kumar, N., Shrivastav, A., Ahirwar, MK., Singh, S., Shrivastava, N. and Ranjan, R. (2020). Pharmacokinetics of amikacin after repetitive intravenous administration in healthy goats. $J$. Anim. Res., 10(6): 899-905.

Source of Support: None; Conflict of Interest: None

(क) क 
and dissemination of resistance among earlier vulnerable organisms (Lin et al., 2015). In order to counter and or restrict these enzymes, semisynthetic aminoglycosides has been developed (Kondo and Hotta, 1999). Amikacin, one of the most important semisynthetic aminoglycosides, was synthesized by acylation of the kanamycin A (Ramirez and Tolmasky, 2017). It can be used alone or in combination with other antibiotics, to treat a variety of serious infections caused by aerobic gram-negative bacteria, as well as Mycobacteria and Nocardia (Tamma et al., 2012; Yuan, 2015). This antibiotic is also essential in the treatment of life-threatening infections (Tayman et al., 2011; Pacifici and Marchini, 2017). Due to its property of being refractory to most of the aminoglycoside modifying enzymes, amikacin has been successfully used to treat the aminoglycoside resistant infections (Marsot et al., 2017; Pacifici and Marchini, 2017). Since, amikacin exhibits serious adverse effects (ototoxicity and nephrotoxicity) common to aminoglycosides, the dosage regimen of drug to maximize therapeutic outcomes and minimize adverse consequences is of great importance (White et al., 2015). Hence, the present study was undertaken to investigate whether the dosage regimen of amikacin calculated from single I/V administration actually maintains the minimum inhibitory concentration (MIC) at the end of every dosage interval during repetitive administration or not.

\section{MATERIALS AND METHODS}

\section{Experimental animals}

The experiment was performed in four clinically healthy female goats of Sirohi breed between 1 to 2 years of age and 15 to $25 \mathrm{~kg}$ body weight. The experimental animals were maintained in the College of Veterinary Science and Animal Husbandry, Rewa (M.P.) under uniform managemental conditions for 3 weeks. The animals were dewormed before the commencement of the study. During the entire period of experiment, animals were subjected to regular clinical examination, and maintained on dry as well as green fodder, concentrate and a routine grazing for at least 4 to 5 hours a day. Clean potable drinking water was provided ad libitum. All the animals were apparently healthy during the study. The experimental protocol for general procedure and use of animals for conducting the present study has been reviewed and approved by the
Institutional Animal Ethics Committee (IAEC), College of Veterinary Science \& AH, Rewa, Madhya Pradesh, India,

\section{Chemicals}

Injectable commercial preparation containing amikacin equivalent to $250 \mathrm{mg} / \mathrm{ml}$ (Amidac India) was used in the present investigation. Antibiotic media no. 1 and 11 were procured from HiMedia laboratories Pvt. Ltd., Mumbai.

\section{Test organism}

Escherichia coli (ATCC 25922) as test organism was used for estimation of concentration of the drugs in plasma by microbiological assay technique obtained from the national collection of industrial micro-organism (NCIM) Division of Bio-chemical sciences, National Chemical Laboratory, Pune.

\section{Dosage and administration of drugs}

Amikacin was administered at the dose rate of $10 \mathrm{mg} / \mathrm{kg}$ bwt I/V in each of four healthy goats once daily for five consecutive days (Saini and Srivastava, 1998).

\section{Collection of blood samples}

Blood samples (approx.1 ml) were withdrawn from jugular vein into heparinized glass centrifuge tubes on days 1 and 5 of treatment: at $0,2.5,5,10,15,20,30,45 \mathrm{~min}$ and 1 , $1.5,2,3,4,6,8,10,12$ and $24 \mathrm{~h}$ after administration of the drug. On days 2, 3 and 4 blood samples were taken 1 and $6 \mathrm{~h}$ after drug administration. Plasma was separated by centrifugation at 3,000 rpm for $15 \mathrm{~min}$ at room temperature and kept at $-4^{\circ} \mathrm{C}$ until analysis, which was usually done within two days of collection of the samples.

\section{Estimation of amikacin}

The concentration of amikacin in plasma was estimated by a rapid, specific microbiological assay technique using Escherichia coli as the test organism (Paul et al., 1971).

\section{Bioassay technique}

Punch bioassay technique, which is the modified method of standard cylinder plate bioassay technique was used to 
estimate the concentration of amikacin in plasma. In this technique, only a seed layer with bacteria suspension was poured on assay plates and the wells were prepared on assay plates (Arret et al., 1971).

\section{Pharmacokinetic analysis}

The plasma concentration-time profile of amikacin was used to determine the pharmacokinetic profile for each animal. The gathered data was further subjected to two compartment open model and kinetic parameters were calculated on the basis of Gibaldi and Perrier (1982).

\section{Calculation of dosage regimen}

The dosage regimen for maintaining minimal therapeutic concentration in plasma at the desired dosage intervals $(\tau)$ was calculated using the following equations (Baggot, 1977).

$$
\begin{aligned}
& \mathrm{D}^{*}=\mathrm{C}_{\mathrm{P}}^{\infty} \min . \mathrm{Vd}_{\text {area }} \cdot\left(\mathrm{e}^{\beta \cdot \tau}\right) \\
& \mathrm{D}^{0}=\mathrm{C}_{\mathrm{P}}^{\infty} \min . \mathrm{Vd}_{\text {area }} \cdot\left(\mathrm{e}^{\beta \cdot \tau}-1\right)
\end{aligned}
$$

Where,

$\mathrm{D}^{*}=$ Priming or Loading dose

$\mathrm{D}^{0}=$ Maintenance dose

$\mathrm{C}_{\mathrm{P}}^{\infty}(\min )=$ Desired minimum plasma concentration

$\tau=$ Dosage interval

$e=$ Base of natural logarithm

$\beta$ and $\mathrm{Vd}_{\text {area }}$ was obtained from kinetic study.

\section{Statistical Analysis}

Comparison of concentrations of the drugs in plasma and various kinetic parameters of amikacin on first and last doses after multiple $\mathrm{I} / \mathrm{V}$ administration in goats was compared by using paired ' $t$ ' test (Snedecor and Cochran, 1994).

\section{RESULTS AND DISCUSSION}

Concentrations of amikacin in plasma at various time intervals following multiple $\mathrm{I} / \mathrm{V}$ injection at the dose rate of $10 \mathrm{mg} / \mathrm{kg}$ bwt have been shown in Fig. 1. The plot (semi logarithm) of plasma levels of amikacin as a function of time after its multiple once daily I/V dose exhibited two distinct phases on $1^{\text {st }}$ and $5^{\text {th }}$ day of drug administration and the data obtained were adequately described by two compartment open model, in the present study. The two-compartment open model after I/V administration of amikacin has been reported in calves (Saini and Shrivastava, 1998) camel (Wasfi et al., 1999), lactating goat (Abo el sooud, 1999), dogs (Baggot et al., 1985) and goats (Uppal et al., 1992). Though Zhou et al. (1997) exhibited first compartment open model in mice.

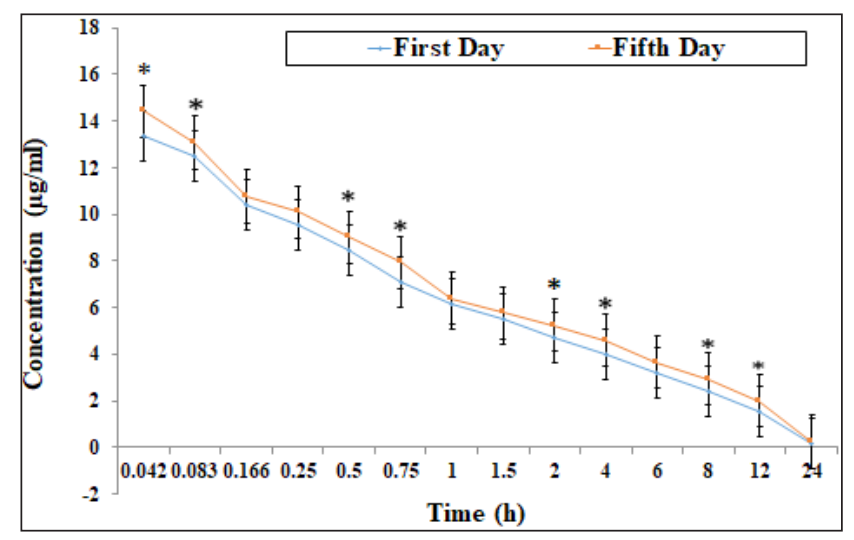

Fig. 1: Comparative plasma concentration of amikacin on $1^{\text {st }}$ and $5^{\text {th }}$ day after I/V administration in healthy goats; ${ }^{*}$ Significant difference $(\mathrm{p} \leq 0.05)$.

The mean peak plasma concentration at 2.5 min was 13.37 $\pm 0.69 \mu \mathrm{g} / \mathrm{ml}$ on $1^{\text {st }}$ day and $14.42 \pm 0.73 \mu \mathrm{g} / \mathrm{ml}$ on $5^{\text {th }}$ day following multiple once daily $\mathrm{I} / \mathrm{V}$ dose of amikacin in healthy goat. Amikacin was detected up to $24 \mathrm{~h}$ with a mean plasma concentration $00.19 \pm 0.02$ on $1^{\text {st }}$ day and $00.24 \pm 0.02 \mu \mathrm{g} / \mathrm{ml}$ on $5^{\text {th }}$ day. The minimum therapeutic concentration $(\geq 1.0 \mu \mathrm{g} / \mathrm{ml})$ of amikacin was maintained up to $12 \mathrm{~h}$ in both $1^{\text {st }}$ and $5^{\text {th }}$ day after drug administration. The significantly higher plasma concentrations of the drug appeared at $0.042,0.83,0.50,0.75,2,4,8,12 \mathrm{~h}$ except $0.166,0.25,1.0,1.5,6,24 \mathrm{~h}$ on $5^{\text {th }}$ day as compared to $1^{\text {st }}$ day of drug administration. It might be due to cumulative effect of drug after repetitive administration at particular interval of time till $5^{\text {th }}$ day. The study conducted by Bhat and Kumar (2019) found that the higher mean peak plasma concentration at $2.5 \mathrm{~min}$ was $24.69 \pm 0.011 \mu \mathrm{g} / \mathrm{ml}$ on $1^{\text {st }}$ day and $25.56 \pm 0.097 \mu \mathrm{g} / \mathrm{ml}$ on $5^{\text {th }}$ day after a multiple once daily I/V dose (10 mg/kg bwt) of amikacin in healthy cow calves and drug was detected up to $10 \mathrm{~h}$ with a mean 
Table 1: Comparison of pharmacokinetic parameters of amikacin after I/V administration in healthy goats between $1^{\text {st }}$ and $5^{\text {th }}$ day (Mean \pm SE)

\begin{tabular}{lll}
\hline Parameter (Unit) & $\mathbf{1}^{\text {st }}$ day & $\mathbf{5}^{\text {th }}$ day \\
\hline $\mathrm{A}(\mu \mathrm{g} / \mathrm{ml})$ & $4.82 \pm 1.28$ & $3.74 \pm 1.13$ \\
$\mathrm{~B}(\mu \mathrm{g} / \mathrm{ml})$ & $7.39 \pm 0.54$ & $8.46 \pm 0.91^{*}$ \\
$\mathrm{C}_{\mathrm{p}}{ }^{\mathrm{o}}(\mu \mathrm{g} / \mathrm{ml})$ & $12.22 \pm 0.46$ & $12.22 \pm 0.47$ \\
$\beta\left(\mathrm{h}^{-1}\right)$ & $0.15 \pm 0.00$ & $0.14 \pm 0.01$ \\
$\alpha\left(\mathrm{h}^{-1}\right)$ & $2.09 \pm 0.44$ & $1.38 \pm 0.55^{*}$ \\
$\mathrm{t}_{1 / 2} \alpha(\mathrm{h})$ & $0.40 \pm 0.11$ & $1.04 \pm 0.49$ \\
$\mathrm{t}_{1 / 2} \beta(\mathrm{h})$ & $4.75 \pm 0.12$ & $4.88 \pm 0.21$ \\
$\mathrm{AUC}(\mu \mathrm{g} / \mathrm{ml} \cdot \mathrm{h})$ & $55.20 \pm 2.91$ & $63.93 \pm 3.68^{*}$ \\
$\mathrm{AUMC}\left(\mu \mathrm{g} / \mathrm{ml} \cdot \mathrm{h}^{2}\right)$ & $370.55 \pm 20.85$ & $450.05 \pm 25.62^{*}$ \\
$\mathrm{MRT}(\mathrm{h})$ & $6.65 \pm 0.09$ & $6.98 \pm 0.17$ \\
$\mathrm{~K}_{12}\left(\mathrm{~h}^{-1}\right)$ & $0.76 \pm 0.28$ & $0.45 \pm 0.25^{*}$ \\
$\mathrm{~K}_{21}\left(\mathrm{~h}^{-1}\right)$ & $1.25 \pm 0.15$ & $0.87 \pm 0.28^{*}$ \\
$\mathrm{Kel}\left(\mathrm{h}^{-1}\right)$ & $0.24 \pm 0.02$ & $0.20 \pm 0.02$ \\
$\mathrm{Vd}_{\text {area }}(\mathrm{L} / \mathrm{kg})$ & $1.25 \pm 0.09$ & $1.10 \pm 0.23$ \\
$\mathrm{Cl}_{\mathrm{B}}(\mathrm{ml} / \mathrm{kg} / \mathrm{h})$ & $181.35 \pm 9.40$ & $161.81 \pm 4.99^{*}$ \\
\hline
\end{tabular}

Zero-time concentration during distribution phase (A); Zero-time concentration during elimination phases (B); Theoretical zero time concentration $\left(\mathrm{C}_{\mathrm{p}}{ }^{\circ}\right)$; Elimination rate constant $(\beta)$; Distribution rate constant $(\alpha)$; Distribution half-life $\left(\mathrm{t}_{1 / 2} \alpha\right)$; Elimination half-life $\left(\mathrm{t}_{1 / 2} \beta\right)$; area under curve (AUC); Area under first moment curve (AUMC); Mean residence time (MRT); Elimination of drug from central compartment $(\mathrm{Kel})$; Volume of distribution $(\mathrm{Vd})$; Total body clearance $\left(\mathrm{Cl}_{\mathrm{B}}\right)$; Rate of transfer of drug from central to peripheral compartment $\left(\mathrm{K}_{12}\right)$ and from peripheral compartment to central $\left(\mathrm{K}_{21}\right)$; *Significant difference $(\mathrm{p} \leq 0.05)$.

Table 2: Comparative dosage regimens for amikacin after I/V administration in healthy goats (Mean \pm S.E.)

\begin{tabular}{llll}
\hline $\mathbf{C P}^{\infty} \mathbf{m i n}(\mu \mathbf{g} / \mathbf{m l})$ & $\tau(\mathbf{h})$ & Dose & Amikacin $(\mathbf{m g} / \mathbf{k g}$ bwt $)$ \\
\hline 1 & 12 & $\mathrm{D}$ & $07.02 \pm 0.36$ \\
& & $\mathrm{D}^{0}$ & $05.91 \pm 0.15$ \\
2 & 12 & $\mathrm{D}$ & $14.32 \pm 0.48$ \\
& & $\mathrm{D}^{0}$ & $11.83 \pm 0.31$ \\
\hline
\end{tabular}

$\mathrm{CP}^{\infty} \min =$ Minimum therapeutic concentration in plasma $(\mathrm{MIC}) ; \tau(\mathrm{h})=$ Dosage interval; $\mathrm{D}^{*}=$ Loading or priming dose; $\mathrm{D}^{\mathrm{o}}=$ Maintenance dose.

plasma concentration of $0.08 \pm 0.002 \mu \mathrm{g} / \mathrm{ml}$ on $1^{\text {st }}$ day and $0.09 \pm 0.002 \mu \mathrm{g} / \mathrm{ml}$ on $5^{\text {th }}$ day. Another study conducted by Orsini et al. (1985) indicated that doses of amikacin at the rate of $4.40,6.60$ and $11.00 \mathrm{mg} / \mathrm{kg}$ bwt showed the concentrations at the level of $30.30 \pm 0.30,61.20 \pm 6.90$ and $122.80 \pm 7.40 \mu \mathrm{g} / \mathrm{ml}$, respectively at $15 \mathrm{~min}$ following $\mathrm{I} / \mathrm{V}$ administration in horse.

The distribution half-life $\left(\mathrm{t}_{1 / 2} \alpha\right)$ of amikacin in goat following multiple once daily $\mathrm{I} / \mathrm{V}$ administration in the present study was $0.40 \pm 0.11 \mathrm{~h}$ on $1^{\text {st }}$ day and while 1.04 $\pm 0.49 \mathrm{~h}$ on $5^{\text {th }}$ day. Bhat and Kumar (2019) reported $t_{1 / 2} \alpha$ of amikacin in cow calves was $0.182 \pm 0.002 \mathrm{~h}$ on $1^{\text {st }}$ day and $0.181 \pm 0.005 \mathrm{~h}$ on $5^{\text {th }}$ day following multiple once daily $\mathrm{I} / \mathrm{V}$ administration. The value of $\mathrm{t}_{1 / 2} \alpha$ reported in goat to be $0.24 \mathrm{~h}$ (Uppal et al., 1997), $0.36 \mathrm{~h}$ in calves and 0.43 $\mathrm{h}$ in sheep (Carli et al., 1990).

The elimination half-life $\left(t_{1 / 2} \beta\right)$ is the time taken for plasma concentration in the body to be reduced by its half (50\%). Half-life provides a good indicator of time which is required to reach steady state after initiation of dosage regimen. The $t_{1 / 2} \beta$ of amikacin in goat following multiple once daily $\mathrm{I} / \mathrm{V}$ administration in the present study was 4.75 $\pm 0.12 \mathrm{~h}$ on $1^{\text {st }}$ day and while $4.88 \pm 0.21 \mathrm{~h}$ on $5^{\text {th }}$ day. Bhat and Kumar (2019) found the $t_{1 / 2} \beta$ of amikacin to be 1.83 $\pm 0.012 \mathrm{~h}$ on $1^{\text {st }}$ day and $1.91 \pm 0.010 \mathrm{~h}$ on $5^{\text {th }}$ day in cow calves, following multiple once daily I/V administration. The $t_{1 / 2} \beta$ of amikacin is more or less similar to $3.09 \pm$ $0.27 \mathrm{~h}$ in bovine calves (Saini and Shrivastava, 1998), in 
lactating sheep $1.64 \pm 0.06 \mathrm{~h}$ (Haritova, 2004) and $2.16 \pm$ $0.45 \mathrm{~h}$ for goats (Uppal et al., 1992).

The high values of AUC and AUMC reflect that most of the body area is covered with the drug concentrations. The AUC values of amikacin in goat after multiple once daily $\mathrm{I} / \mathrm{V}$ administration in the present study was $55.20 \pm 2.91$ $\mu \mathrm{g} / \mathrm{ml} . \mathrm{h}$ on $1^{\text {st }}$ day and $63.93 \pm 3.68 \mu \mathrm{g} / \mathrm{ml}$.h on $5^{\text {th }}$ day. Bhat and Kumar (2019) found the AUC values to be lower i.e. $13.3 \pm 0.051 \mu \mathrm{g} / \mathrm{ml} . \mathrm{h}$ on $1^{\text {st }}$ day and $13.67 \pm 0.042 \mu \mathrm{g} /$ $\mathrm{ml}$.h on $5^{\text {th }}$ day after multiple once daily $\mathrm{I} / \mathrm{V}$ administration of amikacin. The higher AUC values has been recorded in goats $73.18 \mu \mathrm{g} / \mathrm{ml} . \mathrm{h}$ (Agrawal et al., 2001), lactating sheep $94.09 \pm 6.95 \mu \mathrm{g} / \mathrm{ml} . \mathrm{h}$ (Haritova, 2004) and Greyhounds dogs $79.97 \mu \mathrm{g} / \mathrm{ml} . \mathrm{h}$ (Kukanich and Coetzee, 2007). Similarly, the AUMC values of amikacin in goat following multiple once daily $\mathrm{I} / \mathrm{V}$ administration in the present study was $370.55 \pm 20.85 \mu \mathrm{g} / \mathrm{ml} . \mathrm{h}^{2}$ on $1^{\text {st }}$ day and $450.05 \pm 25.62 \mu \mathrm{g} /$ $\mathrm{ml} . \mathrm{h}^{2}$ on $5^{\text {th }}$ day. Bhat and Kumar (2019) reported lower AUMC values $22.7 \pm 0.266 \mu \mathrm{g} / \mathrm{ml}^{2} \mathrm{~h}^{2}$ on $1^{\text {st }}$ day and 24.57 $\pm 0.229 \mu \mathrm{g} / \mathrm{ml} . \mathrm{h}^{2}$ on $5^{\text {th }}$ day after multiple once daily I/V administration of amikacin in cow calves.

The MRT values of amikacin in goat following multiple once daily $\mathrm{I} / \mathrm{V}$ administration in the present study was $6.65 \pm 0.09 \mathrm{~h}$ on $1^{\text {st }}$ day and $6.98 \pm 0.17 \mathrm{~h}$ on $5^{\text {st }}$ day. But lower MRT value of amikacin was reported in cow calves following multiple once daily $\mathrm{I} / \mathrm{V}$ administration i.e. 1.70 $\pm 0.02 \mathrm{~h}$ on $1^{\text {st }}$ day and $1.82 \pm 0.012 \mathrm{~h}$ on $5^{\text {th }}$ day (Bhat and Kumar, 2019). Similar MRT values observed in goat 4.67 $\pm 0.19 \mathrm{~h}$ (Agrawal et al., 2001) and oryx $2.27 \mathrm{~h}$ (Kathryn et al., 1995).

The values for volume of distribution $\left(\mathrm{Vd}_{\text {area }}\right)$ of amikacin in goat following multiple once daily $\mathrm{I} / \mathrm{V}$ administration in the present study was $1.25 \pm 0.09 \mathrm{~L} / \mathrm{kg}$ on $1^{\text {st }}$ day and $1.10 \pm 0.23 \mathrm{~L} / \mathrm{kg}$ on $5^{\text {th }}$ day. The higher $\mathrm{Vd}_{\text {area }}$ was observed in cow calves following multiple once daily $\mathrm{I} / \mathrm{V}$ administration i.e. $1.99 \pm 0.007 \mathrm{~L} / \mathrm{kg}$ on $1^{\text {st }}$ day and $2.02 \pm 0.007 \mathrm{~L} / \mathrm{kg}$ on $5^{\text {th }}$ day (Bhat and Kumar, 2019). However, lower $\mathrm{Vd}_{\text {area }}$ was found in bovine calves $0.40 \pm$ $0.03 \mathrm{~L} / \mathrm{kg}$ (Saini and Shrivastava, 1998), in human 0.27 $\pm 0.04 \mathrm{~L} / \mathrm{kg}$ (Bauer and Blouin, 1983) and Beagle dog $234.00 \mathrm{ml} / \mathrm{kg}$ (Kukanich and Coetzee, 2007). This reflects good penetration of amikacin into various body fluids and tissues of goat and bovine calves. A very high value of $\mathrm{Vd}_{\text {area }}$ obtained in the present study may be attributed to wide distribution of amikacin in the body because of its polar organic base nature (Carli et al., 1990).

The total body clearance $\left(\mathrm{Cl}_{\mathrm{B}}\right)$ values of amikacin in goat following multiple once daily $\mathrm{I} / \mathrm{V}$ administration in the present study was $181.35 \pm 9.40 \mathrm{ml} / \mathrm{kg} / \mathrm{h}$ on $1^{\text {st }}$ day and $161.81 \pm 4.99 \mathrm{ml} / \mathrm{kg} / \mathrm{h}$ on $5^{\text {th }}$ day. The higher $\mathrm{Cl}_{\mathrm{B}}$ values of amikacin observed in cow calves following multiple once daily I/V administration was $754.66 \pm 2.68 \mathrm{ml} /$ $\mathrm{kg} / \mathrm{h}$ on $1^{\text {st }}$ day and $732.994 \pm 2.187 \mathrm{ml} / \mathrm{kg} / \mathrm{h}$ on $5^{\text {th }}$ day (Bhat and Kumar, 2019). The lower $\mathrm{Cl}_{\mathrm{B}}$ values noted after $\mathrm{I} / \mathrm{M}$ administration in goats was $2.34 \pm 0.17 \mathrm{ml} / \mathrm{kg} / \mathrm{min}$ (Agrawal et al., 2001) and in camel as $0.97 \mathrm{ml} / \mathrm{kg} / \mathrm{min}$ (Wasfi et al., 1999). The $\mathrm{Cl}_{\mathrm{B}}$ values in normal condition in cow calves was $0.09 \pm 0.002 \mathrm{~L} / \mathrm{kg} / \mathrm{h}$ which is higher than that of febrile condition $0.05 \pm 0.01 \mathrm{~L} / \mathrm{kg} / \mathrm{h}$ after I/V administration of amikacin (Saini and Shrivastava, 1997). This difference in the values of $\mathrm{Cl}_{\mathrm{B}}$ amongst various species of the animals indicated respective difference in their glomerular filtration rates of amikacin, which is polar organic base, hence weakly bound to serum proteins and is excreted unchanged into the urine by glomerular filtration (Carli et al., 1990).

The ultimate objective of the study of disposition kinetics is to determine an appropriate dosage regimen of amikacin. The dosage regimen for any antimicrobial agent is calculated to maintain the minimum therapeutic concentration $\left(\mathrm{C}_{\mathrm{p}}^{\infty} \mathrm{min}=\mathrm{MIC}\right)$ throughout the course of infection. An average plasma concentration of 1.0-4.0 $\mu \mathrm{g} / \mathrm{ml}$ has been reported to be the minimum therapeutic concentration $\left(\mathrm{MIC}_{90}\right)$ of amikacin against most gram positive, gram negative and atypical bacteria (Leroy et al.,1978; Agrawal et al., 2001). Amikacin possessed excellent antibacterial activity (MIC for $90 \%$ of tested strains i.e. $\mathrm{MIC}_{90}<2.0 \mu \mathrm{g} / \mathrm{ml}$ ) against most common gram-negative aerobic pathogens, including $E$. coli, $K$. pneumonia, Enterobacter spp., Brucella spp. (Shaffer et al., 1953), and Mycobacteria (Suter, 1952). Thus, in the present study, the dosage regimen was derived at MIC of 1.0 and $2.0 \mu \mathrm{g} / \mathrm{ml}$ for amikacin at dosage interval of $12 \mathrm{~h}$ (Table 02). Conclusively, the calculated dosage regimens of amikacin for $\mathrm{C}_{\mathrm{p}}{ }^{\infty} \mathrm{min}=1.0 \mu \mathrm{g} / \mathrm{ml}$ were $07.02 \pm 0.36$ $\mathrm{mg} / \mathrm{kg}$ bwt $\left(\mathrm{D}^{*}\right)$ and $05.91 \pm 0.15 \mathrm{mg} / \mathrm{kg}$ bwt $\left(\mathrm{D}^{0}\right)$ and for $\mathrm{C}_{\mathrm{p}}^{\infty} \mathrm{min}=2.0 \mu \mathrm{g} / \mathrm{ml}$ were $14.32 \pm 0.48 \mathrm{mg} / \mathrm{kg}$ bwt $\left(\mathrm{D}^{*}\right)$ and $11.83 \pm 0.31 \mathrm{mg} / \mathrm{kg}$ bwt $\left(\mathrm{D}^{0}\right)$ respectively at $12 \mathrm{~h}$ dosage intervals $(\tau)$. 


\section{ACKNOWLEDGEMENTS}

The authors are grateful to College of Veterinary Science \& A.H., Rewa (Nanaji Deshmukh Veterinary Science University, Jabalpur, Madhya Pradesh, India) for providing necessary facilities to carry out the present investigation

\section{REFERENCES}

Aboel-Sooud, K. 1999. Pharmacokinetics of amikacin in lactating goats. J. Vet. Med., 46(4): 239-246.

Agrawal, A.K., Singh, S.D. and Jayachandran, C. 2001. Pharmacokinetics of amikacin in goats after single Intramuscular administration. Ind. J. Pharmacol., 33: 374377.

Agrawal, A.K., Singh, S.D. and Jayachandran, C. 2002. Comparative pharmacokinetics and dosage regimen of amikacin in afebrile and febrile goats. Ind. J. Pharmacol., 34: 356-360.

Arret, B., Johnoson D.P. and Kirshaum, A. 1971. Outline of details for microbiological assay of antibiotics. J. Pharm. Sci., 49: 34-38.

Baggot, J.D., Ling, G.V. and Chatfield, R.C. 1985. Clinical pharmacokinetics of amikacin in dogs. Am. J. Vet. Res., 46(8): 1793-6.

Bauer, L.A. and Blouin, R.A. 1983. Influence of age on amikacin pharmacokinetics in patients without renal disease. Comparison with gentamycin and tobramycin. Eur. J. Clin. Pharmacol., 24: 639-642.

Bhat, A.R. and Kumar, N. 2019. A multiple once daily dose pharmacokinetic of amikacin in Cow calves following intravenous administration. J. Vet. Pharmacology and Toxicology, 18(2): 49-54.

Carli, S., Montesissa, C., Sanzogni, O., Madonna, M. and Said, F.A. 1990. Comparative pharmacokinetics of amikacin sulfate in calves and sheep. Res. Vet. Sci., 48: 231-234.

Gibaldi, M. and Perrier,D. 1982. Pharmacokinetics. $2^{\text {nd }}$ Ed., Marcell Dakker, Inc. New York, pp. 433-444.

Haritova, A. 2004. Pharmacokinetics of amikacin in lactating sheep. J. Vet. Res. Commun., 28(5): 429-435.

Houghton, J.L., Green, K.D., Chen, W. and Garneau-Tsodikova, S. 2010. The future of aminoglycosides: The end or renaissance? Chem. Bio. Chem., 11: 880-902.

Kathryn C.G., James, M.J., Dawn, M.B., Heatley J.J. and Kelly, E.H. 1995. Pharmacokinetics of amikacin in Scimitar-Horned Oryx (Oryx dammah) from a Single Intravenous Dose. J. Zoo and Wildlife Med., 26(3): 359-366.

Kondo, S. and Hotta, K. 1999. Semisynthetic aminoglycoside antibiotics: Development and enzymatic modifications. $J$. Infect. Chemother., 5: 1-9.
Kukanich, B. and Coetzee, J.F. 2007. Comparative pharmacokinetics of amikacin in Greyhound and Beagle dogs. J. Vet. Pharmacol. Ther, 31(2): 102-107.

Leroy, A., Humbert, G., Oksenhendler, G. and Fillastre, J.P. 1978. Pharmacokinetis of aminoglycosides in subjects with normal and impaired renal function. Antibiotic chemother., 25: $163-180$.

Lin, J., Nishino, K., Roberts, M.C., Tolmasky, M., Aminov, R.I. and Zhang, L. 2015. Mechanisms of antibiotic resistance. Front. Microbiol., 6(34): 1-3.

Marsot, A., Guilhaumou, R., Riff, C. and Blin, O. 2017. Amikacin in critically ill patients: A review of population pharmacokinetic studies. Clin. Pharmacokinet., 56: 127-138.

Orsini, J.A., Soma, L.R., Rourke J.E. and Park, M. 1985. Pharmacokinetics of amikacin in the horse following intravenous and intramuscular administration. J. Vet. Pharmacol. Therap., 8: 194-201.

Pacifici, G. and Marchini, G. 2017. Clinical pharmacokinetics of amikacin in neonates. Int. J. Pediatr., 5: 4407-4428.

Paul, B.M., Jeanette, W. and Gary, D.O. 1971. Rapid, Specific Microbiological Assay for Amikacin (BB-K8). Antimicrob Agents Chemother., 6(4): 498-500.

Ramirez, M.S. and Tolmasky, M.E. 2017. Amikacin: Uses, Resistance, and Prospects for Inhibition. Molecules, 22(12): 2267.

Saini, S.P. and Srivastava, A.K. 1997. Pharmacokinetics and dosage regimen of amikacin in febrile cow calves. Ind. J. Ani. Sci., 67: 471-473.

Saini, S.P. and Srivastava, A.K. 1998. The disposition kinetics, urinary excretion and dosage regimen of amikacin in cross bred bovine calves. Vet. Res. Commun., 22: 59-65.

Shaffer, J.M., Kucera, C.J. and Spink, W.W. 1953. The protection of intracellular Brucella against therapeutic agents and the bactericidal action of serum. J. Exp. Med., 97: 77-90.

Snedecor, G.W. and Cochran, W.G. 1994. Statistical Methods. Publ., Oxford and IBH Publishing co., New Delhi, pp. 445.

Suter, E. 1952. Multiplication of tubercle bacilli within phagocytes cultivated in vitro and effect of streptomycin and isonicotinic acid hydrazide. Am. Rev. Tubercu. Pulmon. Dis., 65: 775-776.

Tamma, P.D., Cosgrove, S.E. and Maragakis L.L. 2012. Combination therapy for treatment of infections with gramnegative bacteria. Clin. Microbiol. Rev., 25: 450-470.

Tayman, C., El-Attug, M.N., Adams, E., Van Schepdael, A., Debeer, A., Allegaert, K. and Smits, A. 2011. Quantification of amikacin in bronchial epithelial lining fluid in neonates. Antimicrob. Agents Chemother., 55: 3990-3993. 
Uppal, R.P., Verma, S.P., Verma, V. and Garg, S.K. 1997. Comparative pharmacokinetics of amikacin following a single intramuscular or subcutaneous administration in goats (Capra hircus). Vet. Res., 28: 565-570.

Uppal, R.P., Verma, S.P., Roy, R.K. and Garg, S.K. 1992. Pharmacokinetics of amikacin sulphate in goats. Ind. J. Pharmacol., 24(2): 123-125.

Wasfi, I.A., Abdel Hadi, A.A., Bashir, A.K., Alhadrami G.A. and Tanira, M.O.M. 1999. Pharmacokinetics of amikacin in the camel. J. Vet. Pharmacol. Ther., 22: 62-64.
White, B.P., Lomaestro, B. and Pai, M.P. 2015. Optimizing the initial amikacin dosage in adults. Antimicrob. Agents Chemother., 59: 7094-7096.

Yuan, S.M. 2015. Mycobacterial endocarditis: A comprehensive review. Rev. Bras. Cir. Cardiovasc., 30: 93-103.

Zhou, R.H., Kimiko, T. and Shigeyuki, N. 1997. Effects of isolation housing and timing of drug administration on amikacin kinetics in mice. ActaPharmacol. Sin., 18(4): 303305. 
